\title{
The clinical importance and role of transduodenal ampullectomy in a villous adenoma: A case report
}

\author{
Ali Aktekin, Selvinaz Ozkara, Can Gönen \\ Haydarpasa Numune Education and Research Hospital, Turkey \\ Correspondence: Ali Aktekin. Address: Barbaros mah. Saka sok. Mert apt. No17 Daire: 4 Üsküdar 34662İstanbul Turkey. \\ Email:draliaktekin@yahoo.com
}

Received: July 26, 2013

Accepted: August 18, 2013

Online Published: August 29, 2013

DOI : $10.5430 /$ jst.v3n5p1

URL: http://dx.doi.org/10.5430/jst.v3n5p1

\begin{abstract}
Ampullary adenoma is a precancerous lesion. Complete resection is required either endoscopically or surgically. We described a 64-year-old female patient with an ampullary adenoma, who was not suitable for endoscopic resection, so resection was performed by transduodenal ampullectomy. An ulcerated $16 \mathrm{~mm} \times 13 \mathrm{~mm}$ hypoechoic ampullary polypoid lesion with high grade dysplasia and without infiltration into muscularis propria layer was reported on endosonographic examination. The electrocautery was used to resect the adenoma of ampulla. Bile and pancreatic ducts were approximated to duodenal wall via an absorbable suture (4-0 and 5-0 polydioxanone). No stent was used for bile and pancreatic ducts. Visualization of biliary and pancreatic drainages confirmed the patency of both ductal systems, which were $10 \mathrm{~mm}$ and 5 $\mathrm{mm}$ in diameters. Patient had no abnormalities related to biliary and pancreatic duct obstructions, and was discharged on postoperative day 8. Lesion had clear margins after transduodenal ampullectomy. In conclusion, although transduodenal ampullectomy (TDA) is technically demanding, our case is clinically important to demonstrate transduodenal ampullectomy is a safe alternative procedure to pancreaticoduodenectomy for adenoma of ampulla if the lesion is not suitable for endoscopic resection.
\end{abstract}

\section{Key words}

Ampullary adenoma, Ampulla of Vater, Ampullary resection, Local resection, Endoscopy

\section{I ntroduction}

Ampullary tumors account for $10 \%$ of periampullary neoplasm. Benign neoplasms of the ampulla of Vater are rare overall and have been identified in $0.04 \%$ to $0.12 \%$ in autopsy series ${ }^{[1]}$. Patients may present with biliary colic or obstructive jaundice when the lesions are large, but more frequently as nonspecific symptoms such as weight loss, vague abdominal pain, dyspepsia, malaise, and anorexia. The widespread use of esophagogastroduodenoscopy and ultrasonography has increased the detection of ampullary neoplasms and increasingly they are found incidentally.

Histologically, ampullary neoplasms include adenomas, adenocarcinomas, and adenosquamous, small-cell, adenoendocrine, and undifferentiated carcinomas. Although classified as benign, ampullary adenomas are premalignant neoplasms arising from the mucosa and follow an adenoma-to-carcinoma sequence ${ }^{[2,3]}$. Ampullary adenomas are 
therefore considered a precancerous lesion, with reported incidence of transformation to invasive or in situ carcinoma ranging from $25 \%$ to $85 \%{ }^{[4]}$. Thus, removal of benign and malignant ampullary lesions is mandatory.

Although malignant tumors arising from the ampulla of Vater exhibit more favorable biological behavior compared to other periampullary tumors, pancreaticoduodenectomy (PD) still remains the standard surgical approach ${ }^{[5-7]}$. However, a TDA may be an alternative, and some times, a more appropriate procedure for the management of benign neoplasms of the ampulla and for those rare patients not deemed fit to undergo a $\mathrm{PD}^{[8]}$. Although local excision of ampullary neoplasms was first described by Halsted in 1899, it failed to achieve widespread acceptance because of the high rate of tumor recurrence ${ }^{[9]}$. In experienced centers, PD is associated with low mortality rates, but high rates of perioperative morbidity ${ }^{[10]}$. Endoscopic papillectomy (EP) can be used as an alternative first-line therapy in selected papillary adenomas and ampullectomy is potentially an attractive alternative in appropriate patients because it may be associated with lower morbidity ${ }^{[11-13]}$.

In this case report, we describe a patient with ampullary adenoma, who was not suitable for endoscopic resection, and discussed clinically importance of TDA and some perspectives of TDA technique.

\section{Case report}

A 64-year-old female patient with a history of cholecystectomy was admitted to our hospital because of abdominal pain. Magnetic resonance cholangiopancreatography (MRCP) showed dilated common bile duct. Endoscopic ultrasound (EUS) examination revealed a $13 \mathrm{~mm}$ to $16 \mathrm{~mm}$ hypoechoic ampullary polypoid lesion without infiltration into layer of muscularis propria. Common bile duct (CBD) stones and a reactive $5 \mathrm{~mm}$ to $9 \mathrm{~mm}$ lymph node were also identified. During endoscopic retrograde cholangiopancreatography (ERCP), an ulcerated ampullary lesion was identified, and multiple biopsies were obtained. Stones were extracted after the sphincterotomy. The mass did not extend into the CBD or pancreatic duct (Figure 1). Endoscopic resection was not attempted because the mass was ulcerative. Pathologic examination of biopsy specimens revealed adenoma with high grade dysplasia.

\subsection{Operation}

After right subcostal incision, abdominal exploration was performed to assess for systemic spread and full exposure of posterior duodenum and bimanual palpation of the ampulla were facilitated by a complete Kocher maneuver. A duodenotomy of approximately $5 \mathrm{~cm}$ long was performed along anterior wall of the second portion overlying tumor. A serial stay suture (4-0 silk) was placed on either side of the duodenotomy to facilitate exposure of the ampulla ${ }^{[13,14]}$. The mass was retracted laterally and excision was begun at the eleven o'clock position. The electrocautery was used to cut posterior duodenal tissues directed toward the lumen of CBD. Once it was entered, bile duct was approximated to the medial duodenal wall via an absorbable suture (4-0 polydioxanone [PDS])). Dissection was then continued and the pancreatic duct was encountered approximately at the two o'clock position ${ }^{[13,14]}$. The absorbable suture (5-0 PDS) was placed to approximate pancreatic duct to duodenal wall. Dissection was continued until the ampullary mass was completely excised. Sequential sutures were placed to approximate CBD and pancreatic duct to duodenal wall. Frozen section of lesion was reported as an adenoma with high grade dysplasia without any invasion and with a safe resection margin. Once all outer sutures were secured, the common walls of the pancreatic duct and CBD were approximated with interrupted absorbable sutures (5-0 PDS). Duodenal defect lateral to anastomosis was closed by placing an absorbable suture (4-0 PDS). Visualization of biliary and pancreatic drainages confirmed patency of both ductal systems, and they were determined as $10 \mathrm{~mm}$ and $5 \mathrm{~mm}$ in diameters when measured after complete biliary and pancreatic anastomoses. No stent was used for biliary and pancreatic ducts. Duodenal closure was performed in the transverse orientation via an absorbable suture (4-0 PDS) was used. A closed drain was used although it was an uncomplicated procedure. 

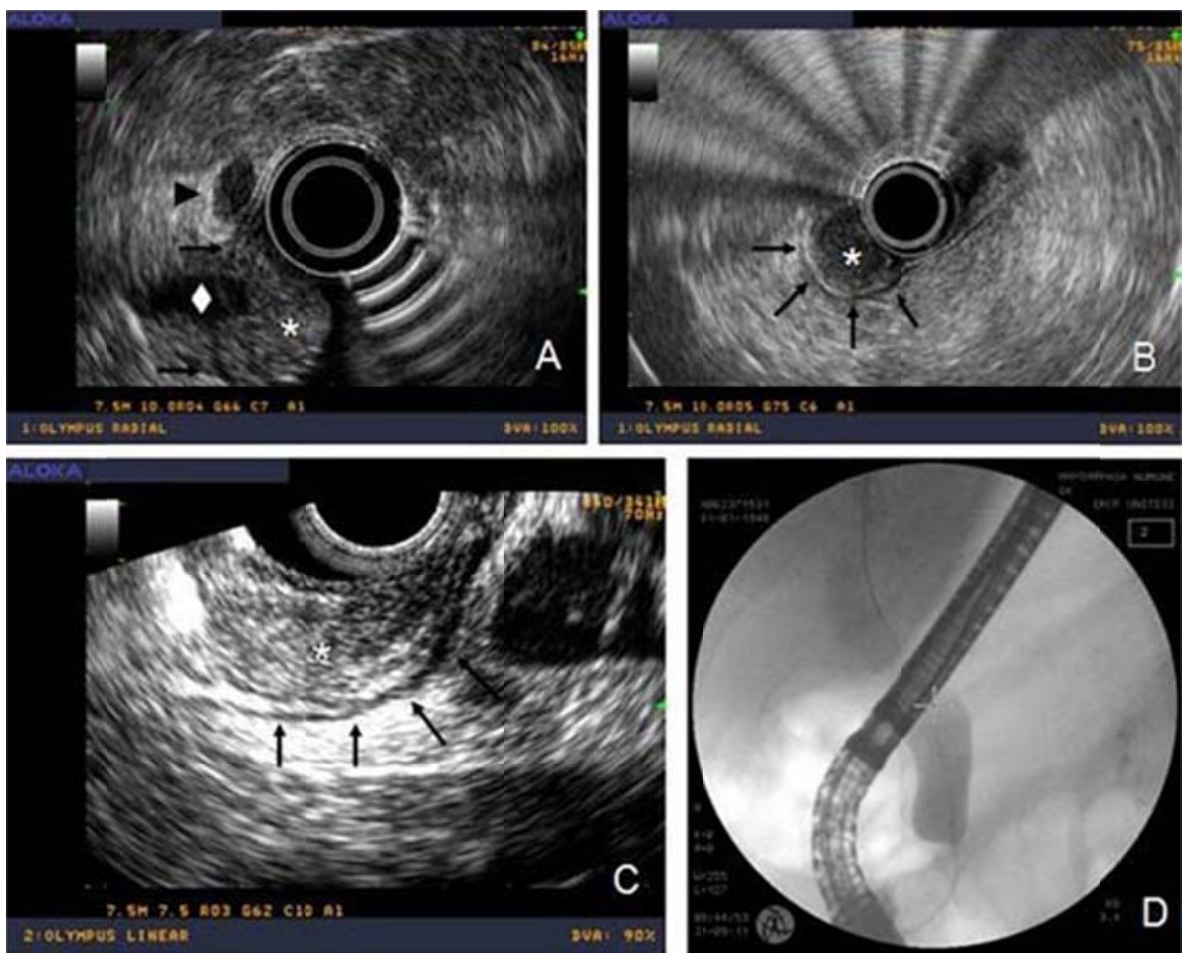

Figure 1. A and B) Radial endosonographic image of the hypoechoic adenoma (asterisks), intact muscularis propria (arrows), common bile duct (diamond) and a reactive lymph node (arrowhead). C) Linear endosonographic image of the same lesion. D) Cholangiogram

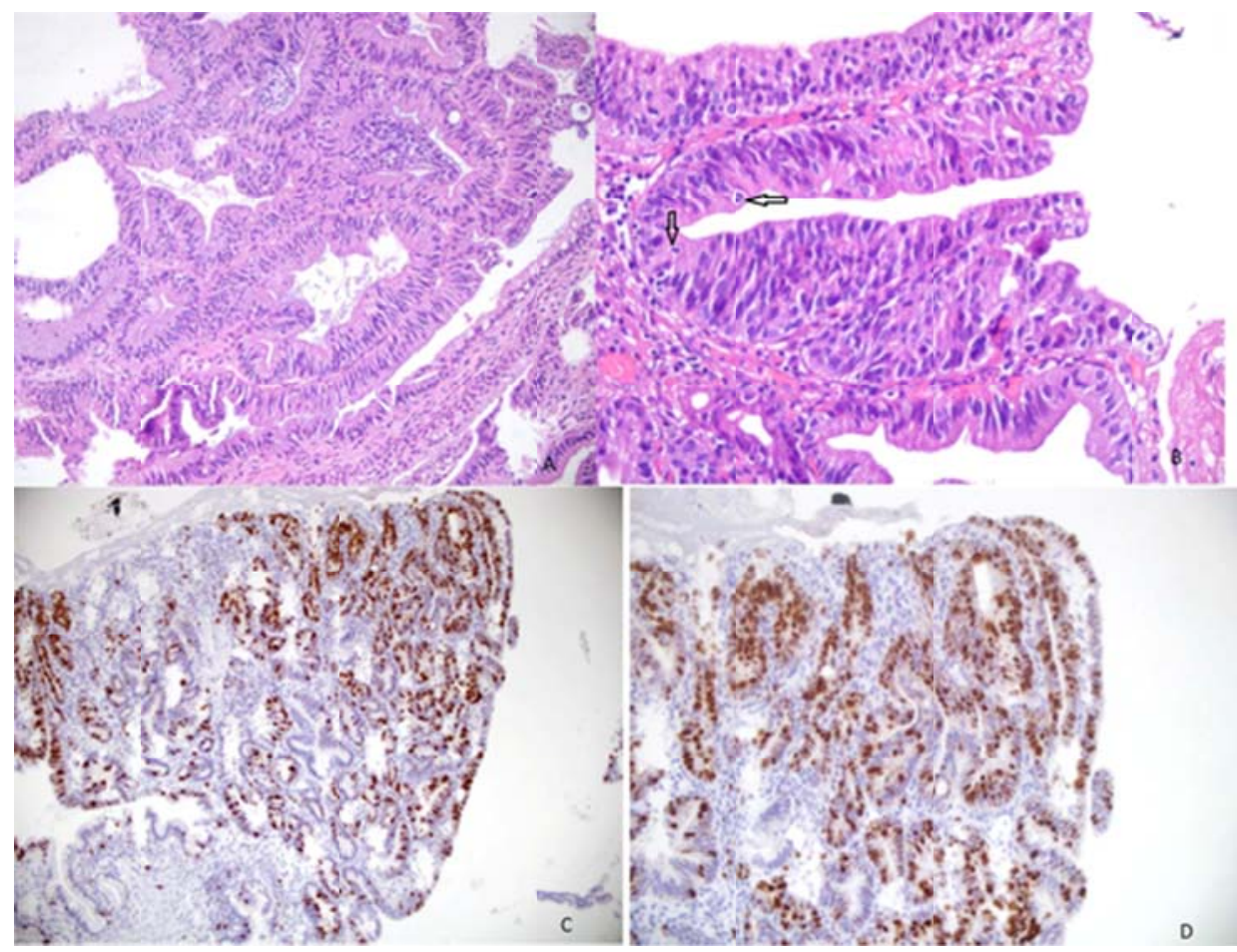

Figure 2. A) The lesions was in villous configurations and also in complex glandular structures (H\&E 200X). B) Epithelium of these structures was mucin depleted and pseudostratified epithelial cells had large elongated hyperchromatic nuclei and mitotic figures (arrows). (H\&E 400X). C and D) Immunohistochemistry staining of the lesion was positive with Ki67 (Immunohistochemistry 40X and 100X) 


\subsection{Postoperative care}

Oral intake was resumed when patient's bowel functions returned normal on the postoperative fourth day. Oral contrast material was not employed during leakage evaluation before the oral intake. Although there was some serous drainage, we measured amylase levels within normal limits before removing the drain, so the drain was removed on the postoperative fifth day. No clinical and laboratory abnormality related to pancreatitis or biliary obstruction was observed in the patient, so she was discharged on the postoperative eighth day.

Microscopic examination of lesion revealed villous configurations, large hyperchromatic nucleated cells and poor mucin content. Epithelium of the lesion was observed pseudostratified in appearance. The dysplastic epithelium was strongly stained with p53, and also shown high proliferation index by Ki67. It was reported as an intestinal type villous adenoma with high grade dysplasia without any invasive components and a clear resection margin (Figure 2).

\section{Discussion}

ERCP and EUS provide useful information in ampullary adenoma assessments, and are useful techniques to assess involvement in depth and intraductal extension in patients with ampullary neoplasms. However, differential diagnosis of a normal ampulla, odditis, or a tumor can be difficult with both techniques in selected cases. False-positive results are reported because of inflammation following stone migration. On the other hand, false-negative findings are result of endoampullary growth or the coexistence of stones leading to diagnostic errors because of similar clinical manifestations ${ }^{[15,16]}$. The endosonography examination of ampullary lesions is important to exclude the invasion level before deciding endoscopic or surgical treatments. Obtaining a biopsy before management is also important. Differential diagnosis between an inflammatory tissue and a low-grade dysplasia adenoma can be difficult even for an experienced pathologist, so repeated biopsies may be required ${ }^{[15]}$. Our case was reported as an ampullary lesion with high grade dysplasia. Lesions with high-grade dysplasia warrant therapy, because they may harbor malignancy, which can be missed during the biopsy, and malign lesion incidence is nearly $26 \%$ in a papillary adenoma ${ }^{[16]}$.

There is no single treatment approach for all lesions. Although endoscopy is the common approach in treatment of papillary adenomas in the recent years, surgery was preferred in our patient because the lesion was ulcerated and had hard consistency with suspicion of malignancy. Moreover, all adenocarcinomas do not require PD, as well as not all benign lesions are suitable for local resection ${ }^{[17]}$. Currently, overall outcomes in ampullectomy are the same or even better than those in PD in villous adenomas and pT1 adenocarcinomas ${ }^{[18]}$. Most recently, a large retrospective series of 102 patients, who were diagnosed with ampullary adenoma and underwent endoscopic resection, indicated success rate of $84 \%{ }^{[19]}$. Factors affecting the success were smaller lesion sizes $(<2 \mathrm{~cm})$, and absence of dilated ducts. Han et al. ${ }^{[12]}$ defined the morbidity rate as $23 \%$ (range $=10 \%-58 \%$ ) and the mortality rate as $0.4 \%$ (range $=0 \%-7 \%$ ). The lesion was smaller than 2 $\mathrm{cm}$, and biliary and pancreatic ducts were dilated in our patient. Kim et al. ${ }^{[20]}$ reported 22 patients who were treated for the ampulla of Vater tumor by performing TDA. Complications were observed in 5 TDA patients without any death events. Our patient was discharged also with no complication.

Surgical literature showed that the most important prognostic factor for survival was complete tumor resection ${ }^{[17]}$. Local recurrence rates are low, if the resection margins are of $1 \mathrm{~cm}$ in adenocarcinoma, and lower than $1 \mathrm{~cm}$ in villous adenoma cases ${ }^{[17,18]}$. Nearly $1 \mathrm{~cm}$ surgical margin was obtained in our patient due to TDA. Moreover, an endoscopic snare resection does not allow a wide resection margin on the pancreatic side, and is associated with higher local recurrence rates, ER indication is restricted as a palliative treatment in patients unfit for surgery or rejecting surgery ${ }^{[21]}$. On the other hand, TDA allows complete circumferential resection of ampulla of Vater by providing precise pathologic examination. In addition frequent endoscopic examinations may be required after EP to achieve clear margin ${ }^{[12,22]}$. Therefore, if a clear resection margin is not obtained by en bloc resection in EP, TDA should be preferred rather than endoscopic piecemeal 
resection. Inadequate resection margin can result in both tumor recurrence, and hinder diagnosis of focal or in situ carcinoma within the adenoma.

It is very important to perform a Kocher maneuver to get under control the surgical field and inspect precise anatomic structures. Hepatic flexure of colon was freed from and the duodenum was mobilized up to left side of vena cava to have such opportunities in our patient. In addition, PDS was performed while anastomozing bile and pancreatic ducts to jejunum during PD. PDS was the strongest and long lasting absorbable suture material in pancreatic juice, so we preferred PDS in the all anastomoses and also in closing duodenotomy ${ }^{[23]}$. Use of stents especially for pancreatic anastomosis is also recommended during TDA, but in our case, both biliary and pancreatic ducts were large and patent, so pancreatic stenting was not performed.

In conclusion, although TDA is technically demanding, our case is clinically important to demonstrate TDA is an accurate and a safe alternative procedure to PD for adenoma of ampulla if the lesion is not suitable for endoscopic resection.

\section{References}

[1] Martin JA, Haber GB. Ampullary adenoma: clinical manifestations, diagnosis, and treatment. GastrointestEndoscClin North Am. 2003; 13 (4): 649-669. http://dx.doi.org/10.1016/S1052-5157(03)00101-6

[2] Chung CH, Wilentz RE, Polak MM, Ramsoekh TB, Noorduyn LA, Gouma DJ, et al. Clinical significance of K-ras oncogene activation in ampullary neoplasms. J ClinPathol. 1996; 49(6): 460-464. PMid:8763258 http://dx.doi.org/10.1136/jcp.49.6.460

[3] Fischer HP, Zhou H. Pathogenesis of carcinoma of the papilla of Vater. J HepatobiliaryPancreat Surg. 2004; 11(5): $301-309$. PMid:15549428 http://dx.doi.org/10.1007/s00534-004-0898-3

[4] Patel R, Davitte J, Varadarajulu S, Wilcox CM. Endoscopic resection of ampullary adenomas: complications and outcomes. Dig Dis Sci. 201; 56(11): 3235-40.

[5] Roggin KK, Yeh JJ, Ferrone CR, Riedel E, Gerdes H, Klimstra DS, et al. Limitations of ampullectomy in the treatment of nonfamilialampullary neoplasms. Ann SurgOncol. 2005; 12(12): 971-980. PMid:16244798

http://dx.doi.org/10.1245/ASO.2005.03.009

[6] de Castro SM, van Heek NT, Kuhlmann KF, Busch OR, Offerhaus GJ, van Gulik TM, et al. Surgical management of neoplasms of the ampulla of Vater: local resection or pancreatoduodenectomy and prognostic factors for survival. Surgery 2004;136 (5):994-1002. PMid:15523392 http://dx.doi.org/10.1016/j.surg.2004.03.010

[7] Farnell MB, Sakorafas GH, Sarr MG, Rowland CM, Tsiotos GG, Farley DR, et al. Villous tumors of the duodenum: reappraisal of local vs. extended resection. J Gastrointest Surg. 2000; 4(1): 13-21. discussion 22-3.

[8] Meneghetti AT, Safadi B, Stewart L, Way LW. Local resection of ampullary tumors. J Gastrointest Surg. 2005; 9(9): $1300-1306$. PMid:16332486 http://dx.doi.org/10.1016/j.gassur.2005.08.031

[9] Halsted WS. Contributions to the surgery of the bile passages, especially of the common bile duct. Boston Med Surg J. 1899;141: 645-654. http://dx.doi.org/10.1056/NEJM189912281412601

[10] Grobmyer SR, Pieracci FM, Allen PJ, Brennan MF, Jaques DP. Defining morbidity after pancreaticoduodenectomy: use of a prospective complication grading system. J Am Coll Surg. 2007; 204 (3):356-364. PMid:17324768 http://dx.doi.org/10.1016/j.jamcollsurg.2006.11.017

[11] Sand JA, Nordback IH. Transduodenal excision of benign adenoma of the papilla of Vater. Eur J Surg. 1995; 161(2): $269-272$. PMid:7612770

[12] Han J, Kim MH. Endoscopic papillectomy for adenomas of the major duodenal papilla (with video). GastrointestEndosc. 2006; 63: 292-301. PMid:16427938 http://dx.doi.org/10.1016/j.gie.2005.07.022

[13] Maithel SK, Fong Y. Technical aspects of performing transduodenalampullectomy. J Gastrointest Surg. 2008; 12(9): $1582-5$. PMid:18213500 http://dx.doi.org/10.1007/s11605-008-0474-2

[14] Distler M, Grützmann R. [Transduodenal resection of ampullary tumors]. ZentralblChir. 2012; 137(4): 319-21. PMid:22933002 http://dx.doi.org/10.1055/s-0032-1315218

[15] Chini P, Draganov PV. Diagnosis and management of ampullary adenoma: The expanding role of endoscopy. World J GastrointestEndosc. 2011; 3(12): 241-247. PMid:22195233 http://dx.doi.org/10.4253/wjge.v3.i12.241

[16] Seifert E, Schulte F, Stolte M. Adenoma and carcinoma of the duodenum and papilla of Vater: a clinicopathologic study. Am J Gastroenterol 1992; 87(1): 37-42. PMid:1728122 
[17] Rattner DW, Fernandez-del Castillo C, Brugge WR, Warshaw AL. Defining the criteria for local resection of ampullary neoplasms. Arch Surg 1996; 131(4): 366-371. PMid:8615720 http://dx.doi.org/10.1001/archsurg.1996.01430160024003

[18] Beger H, Treitschke F, Gansauge F, Harada N, Hiki N, Mattfeldt T. Tumor of the ampulla of Vater: experience with local or radical resection in 171 consecutively treated patients. Arch Surg. 1999; 134(5): 526-532. PMid:10323425 http://dx.doi.org/10.1001/archsurg.134.5.526

[19] Irani S, Arai A, Ayub K, Biehl T, Brandabur JJ, Dorer R, et al. Papillectomy for ampullary neoplasm: results of a single referral center over a 10-year period. GastrointestEndosc. 2009; 70(5): 923-932. PMid:19608181 http://dx.doi.org/10.1016/j.gie.2009.04.015

[20] Kim J, Choi SH, Choi DW, Heo JS, Jang KT. Role of transduodenalampullectomy for tumors of the ampulla of Vater. J Korean Surg Soc. 2011; 81(4): 250-256. PMid:22111080 http://dx.doi.org/10.4174/jkss.2011.81.4.250

[21] Tokunaga Y, Hosogi H, Hoppou T, Nakagami M, Tokuka A, Ohsumi K. A case of ampullary carcinoma successfully managed with endoscopic snare resection. SurgLaparoscEndoscPercutan Tech 2002; 12(4): 273-278; discussion 276-278. PMid:12193823 http://dx.doi.org/10.1097/00129689-200208000-00013

[22] Lee SY, Jang KT, Lee KT, Lee JK, Choi SH, Heo JS, et al. Can endoscopic resection be applied for early stage ampulla of Vater cancer? GastrointestEndosc. 2006; 63(6): 783-788. PMid:16650538 http://dx.doi.org/10.1016/j.gie.2005.09.015

[23] Muftuoglu MA, Ozkan E, Saglam A. Effect of human pancreatic juice and bile on the tensile strength of suture materials. Am J Surg. 2004; 188(2): 200-203. PMid:15249253 http://dx.doi.org/10.1016/j.amjsurg.2003.12.068 